\title{
REFLEKSI KETERWAKILAN PEREMPUAN DALAM PARLEMEN PERSPEKTIF HAK ASASI MANUSIA
}

\author{
Imam Sukadi \\ Fakultas Syariah UIN Maulana Malik Ibrahim Malang \\ E-mail: imam_sukadi@ymail.com
}

\begin{abstract}
Women as nation asset who play a role in resumption process and creation of generation with high quality are require to get guarantee to accomplishment of their rights. Involvement of men and woman in political area is a part that can not be separated in democratization process. Democracy give the largest opportunity to all citizen who have fulfilled the requiremets to be able to select and selected as representative of citizen without discrimination againt tribe, race, religion, and gender. From some general elections which have been executed, representative of women in parliament is still in minimum number. The low of women delegation in parliament can become indicator of the low role of woman in political party.

Perempuan sebagai asset bangsa yang berperan dalam proses penerusan dan penciptaan generasi yang berkualitas perlu mendapatkan jaminan terhadap pemenuhan hak-haknya. Keterlibatan perempuan dan laki-laki di bidang politik adalah bagian tidak terpisahkan dalam proses demokratisasi. Demokrasi memberikan kesempatan seluas-luasnya kepada seluruh warga negara yang memenuhi syarat untuk dapat memilih dan dipilih sebagai wakil rakyat tanpa adanya diskriminasi terhadap suku, ras, agama, dan gender. Dari beberapa pemilu yang sudah dilaksanakan, wakil perempuan diparlemen masih sangat minim. Rendahnya keterwakilan perempuan di parlemen bisa menjadi indikator rendahnya peran perempuan di partai politik.
\end{abstract}

Keywords: perempuan, parlemen, pemilu

\section{Pendahuluan}

Berdasarkan hasil Sensus Penduduk pada tahun 2010 yang dilakukan oleh Badan Pusat Statistik, jumlah perempuan Indonesia adalah sebesar 118.010.413 jiwa atau sekitar $49 \%$ dari total jumlah penduduk Indonesia yang berjumlah 237.641.326 jiwa (www.bps.go.id). Artinya, kondisi ideal keterwakilan perempuan Indonesia dalam lembaga perwakilan seharusnya mencapai rasio yang sama dengan jumlah penduduk Indonesia berjenis kelamin perempuan. Kondisi ini tentu saja sangat ideal, walaupun belum tentu mustahil diwujudkan. Berkaca dari hasil Pemilu selama ini, untuk mencapai angka kritis 30\% sebagaimana ditetapkan sebagai kebijakan khusus sementara bukanlah pekerjaan yang mudah dan sangat membutuhkan dukungan dari banyak pihak, tak terkecuali gerakan perempuan. 
Berdasarkan sensus penduduk di atas, kaum perempuan meliputi hampir separuh dari jumlah umat manusia di Indonesia, dan oleh karena itu setiap pengambilan keputusan, baik dalam urusan pribadi, di dalam keluarga, hingga ke tingkat masyarakat atau kehidupan publik seharusnya senantiasa memperhatikan serta melibatkan peran serta kaum perempuan dalam proses pengambilan keputusan tersebut. Hak-hak politik, sosial dan ekonomi perempuan adalah bagian integral dan tak terpisahkan dari seluruh kerangka hak asasi mereka. Demokrasi adalah sebuah proses inklusif, dan oleh karenanya di dalam kehidupan demokrasi yang sehat semua pandangan atau perspektif dari berbagai kelompok kepentingan harus dipertimbangkan secara seksama dalam tahap perumusan tiap-tiap keputusan. Kepentingan dan pandangan kaum laki-laki, perempuan serta kelompok minoritas merupakan bagian mutlak dari proses pengambilan keputusan.

Sebagai bentuk rasa tanggungjawab terhadap perlindungan hak-hak asasi perempuan, pemerintah Indonesia turut serta dengan masyarakat internasional memperjuangkan hak-hak asasi perempuan, dengan meratifikasi beberapa konvensi internasional. Konvensi internasional yang sudah diratifikasi antara lain adalah :

1. Konvensi tentang Hak-hak Politik Wanita Tahun 1952 menjadi Undangundang Nomor 68 Tahun 1958.

2. Konvensi tentang Penghapusan Segala Bentuk Diskriminasi terhadap Wanita Tahun 1979 (Convention on the Elimination of All Forms of Discrimination Against Woman) menjadi Undang-undang Nomor 7 Tahun 1984.

3. Konvensi Menentang Penyiksaan dan Perlakuan atau Penghukuman Lain Yang Kejam, Tidak Manusiawi, atau Merendahkan Martabat Manusia (Convention Against Torture And Other Cruel, Inhuman or Degrading Treatment or Punishment) menjadi Undang-Undang Nomor 5 Tahun 1998.

Konstitusi Indonesia yaitu UUD NRI 1945 juga telah mengakomodir tentang persaman hak antara laki-laki dan perempuan. Hal ini terlihat dalam bunyi Pasal 27 ayat (1) UUD NRI 1945 yang menyebutkan :

Segala warga negara bersamaan kedudukannya di dalam hukum dan pemerintahan dan wajib menjunjung hukum dan pemerintahan itu dengan tidak ada kecualinya.

Kemudian di dalam Pasal 28 C ayat (2) UUD 1945 menyebutkan, bahwa: Setiap orang berhak untuk memajukan dirinya dalam memperjuangkan haknya secara kolektif untuk membangun masyarakat, bangsa, dan negaranya.

Pasal 28 D ayat (3) UUD 1945 mengatakan :

Setiap warga negara berhak memperoleh kesempatan yang sama dalam pemerintahan.

Berdasarkan bunyi UUD 1945 sebagaimana dikemukakan di atas, terlihat bahwa UUD 1945 tidak membedakan laki-laki dengan perempuan. Hal itu tercermin dari bunyi awal kalimat, yang selalu menyebutkan "Segala warga negara, "Setiap orang", Setiap warga negara". Permasalahannya adalah bahwa apa yang sudah dirumuskan di dalam UUD 1945 tersebut di dalam praktek 
penyelenggaraan negara tidaklah demikian. Kaum perempuan masih saja termarjinalkan baik dalam kehidupan rumah tangga, bidang politik, pemerintahan, maupun dalam mendapatkan pekerjaan.

Keterlibatan perempuan dan laki-laki di bidang politik adalah bagian tidak terpisahkan dalam proses demokratisasi. Mengkaitkan issu gender dengan proses demokratisasi adalah sesuatu yang sudah lazim diterima oleh masyarakat, oleh karena di dalamnya terintegrasi hak-hak politik baik bagi laki-laki maupun perempuan yang merupakan hak asasi manusia paling mendasar. (Suharizal dan Delfina Gusman: 2010)

\section{Keterwakilan Perempuan di Parlemen Dalam Lintasan Sejarah}

Meski negara kini relatif akomodatif terhadap wacana dan tuntutan keterwakilan politik perempuan, namun harus disadari bahwa ruang ekspresi politik perempuan yang diberikan negara (dan para elite partai) masih jauh dari spirit keadilan dan keseteraan. Kendati penetapan kuota 30 persen melalui akomodasi negara sudah di uji-coba sejak pemilu 2004 lalu, namun ditilik dari aspek sejarah pertumbuhan representasi politik perempuan di parlemen, faktual masih berlangsung secara fluktuatif. Catatan representasi politik perempuan menunjukkan angka naik turun dari waktu ke waktu terkait keterlibatan perempuan dalam arena politik praktis, khususnya di lembaga legislatif. Anggota DPR Sementara 1950-1955 misalnya, berhasil mengakomodasi 9 kursi $(3,8 \%)$ dari 236 kursi anggota legislatif terpilih saat itu. Jumlah keterwakilan perempuan hasil Pemilu 1955-1960 naik menjadi 17 kursi (6,3\%) dari 272 anggota parlemen terpilih

Representasi perempuan di parlemen secara kuantitatif kembali naik turun. Di era Konstituante (1956-1959) peroleh kursi legislative perempuan turun menjadi 25 kursi $(5,1 \%)$ dari 488 kursi anggota Konstituante. Bagitu pun di era Orde Baru, keterwakilan politik perempuan di parlemen juga mengalami pasangsurut. Pemilu pertama Orde Baru (1971-1977) berhasil menempatkan perempuan pada 36 kursi parlemen (7,8\%), Pemilu 197729 kursi (6,3\%), dan Pemilu 198239 krusi $(8,5 \%)$ dari 460 anggota DPR terpilih pada tiga periode Pemilu tersebut. Selanjutnya, Pemilu 1987 berhasil menempatkan perempuan pada 65 kursi (13\%) dari 500 kursi DPR, dan terus mengalami penurunan pada Pemilu 1992-1997, 1997-1999, dan 1999-2004 menjadi 62 kursi (12,5\%), 54 kursi (10,8\%), dan 46 kursi (9\%) dari masing-masing 500 kursi yang berhasil di raih anggota DPR dari masing-masing periode pemilu tersebut. Berikutnya, Pemilu 2004 kembali menaikkan jumlah anggota legislatif perempuan menjadi 63 orang $(11,45 \%)$ dari 550 anggota DPR terpilih, dan Pemilu 2009 berhasil menempatkan 99 anggota legislatif perempuan $(17,68 \%)$ dari 560 calon anggota DPR terpilih hasil Pemilu 2009.

Pada Pemilu 2014 lalu, Komisi Pemilihan Umum (KPU) telah menetapkan perolehan jumlah kursi serta calon anggota legislatif (caleg) Dewan Perwakilan Rakyat (DPR) terpilih dalam Pemilihan Umum (Pemilu) tahun 2014 pada tanggal 14 Mei 2014. Partai Demokrasi Indonesia Perjuangan (PDI-P) memimpin perolehan kursi di DPR, sebesar 109 kursi (19,5\%), diikuti oleh Partai Golongan Karya (Golkar) dengan 91 kursi (16,3\%), Partai Gerakan Indonesia Raya (Gerindra) 73 kursi (13,0\%), Partai Demokrat 61 kursi (10,9\%), Partai Amanat Nasional (PAN) 49 kursi (8,8\%), Partai Kebangkitan Bangsa (PKB) 47 kursi 
$(8,4 \%)$, Partai Keadilan Sejahtera (PKS) 40 kursi $(7,1 \%)$, Partai Persatuan Pembangunan (PPP) 39 kursi (7,0\%), Partai Nasional Demokrat (Nasdem) 35 kursi (6,3\%), dan Partai Hati Nurani Rakyat (Hanura) 16 kursi (2,9\%).

Untuk lebih memudahkan, berikut persentase dalam bentuk diagram bagan, anggota DPR RI periode 2014-2019 yakni:

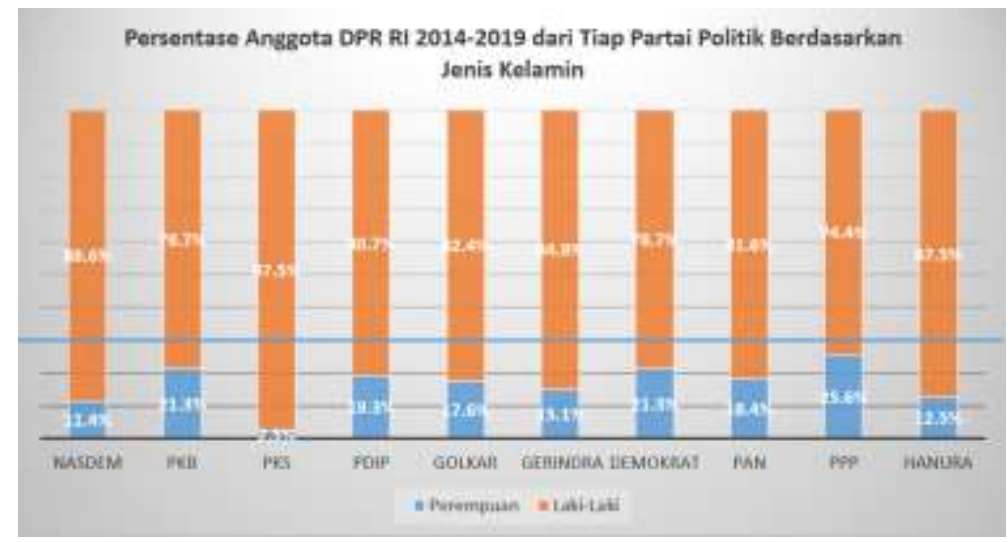

Dari 560 orang caleg terpilih, $79,1 \%$ di antaranya adalah mereka yang menduduki nomor urut satu dan dua dalam Daftar Calon Tetap (DCT). Bila dilihat dari jumlah perolehan suara setiap caleg, posisi 10 caleg dengan suara terbanyak diduduki oleh caleg petahana. Empat orang caleg dengan suara terbanyak berasal dari PDI-P, yaitu: Karolin Margret Natasa, dari daerah Pemilihan (Dapil) Kalimantan Barat dengan 397.481 suara; Puan Maharani dari Dapil Jawa Tengah V dengan 369.927 suara; I Wayan Koster dari Dapil Bali dengan 260.342 suara; dan Rieke Diah Pitaloka dari Dapil Jawa Barat VII dengan 255.064 suara. Meskipun 3 dari 4 orang caleg dengan suara terbanyak adalah caleg perempuan, namun secara keseluruhan jumlah caleg perempuan yang terpilih mengalami penurunan bila dibandingkan dengan hasil pemilu sebelumnya. Jumlah perempuan yang menjadi Anggota DPR RI periode 2014-2019 hanya sekitar 79 orang atau 14\% dari total Anggota DPR RI yang berjumlah 560 orang. (Kompas, 13 Mei 2014). Perhatikan bagan berikut:

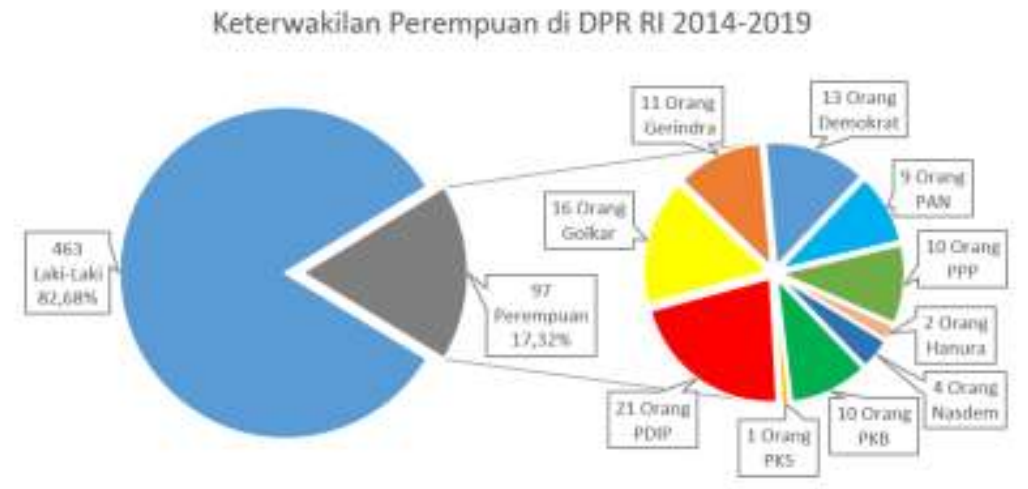

Dari data Perkumpulan untuk Pemilu dan Demokrasi (Perludem), jumlah calon anggota DPR RI perempuan meningkat dari tahun 2009 yang sebesar 33,6\% menjadi $37 \%$ pada tahun 2014. Namun dari data yang dikeluarkan Komisi Pemilihan Umum tentang anggota legislatif terpilih, jumlah anggota DPR RI perempuan yang terpilih pada periode 2014-2019 justru mengalami penurunan. Di tahun 2009, jumlah anggota DPR RI perempuan mencapai 103 orang, atau sebesar 
18\%. Jumlah ini menurun pada tahun 2014 menjadi 97 orang, atau sebesar $17,32 \%$. Rendahnya keterwakilan perempuan di parlemen bisa menjadi indikator rendahnya peran perempuan di partai politik.

\section{Peningkatan Keterwakilan Perempuan di Parlemen Melalui Pemberdayaan}

Perempuan sebagai asset bangsa yang berperan dalam proses penerusan dan penciptaan generasi yang berkualitas perlu mendapatkan jaminan terhadap pemenuhan hak-haknya dan perlindungan dari tindak kekerasan dan diskriminasi. Selain perempuan harus dilindungi, agar pada perkembangannya semakin bisa menjaga dirinya sendiri maka perempuan harus diberdayakan. Pemberdayaan ini penting ditujukan pada kesetaraan gender yaitu suatu kondisi bagi laki-laki dan perempuan untuk memperoleh kesempatan dan hak-haknya sebagai manusia agar mampu berperan dan berpartisipasi dalam kegiatan politik, ekonomi, sosial budaya, pertahanan dan keamanan nasional, dan kesamaan dalam menikmati hasil pembangunan.

Pemberdayaan merupakan transformasi hubungan kekuasaan antara lakilaki dan perempuan pada empat level yang berbeda, yakni keluarga, masyarakat, pasar dan negara. Konsep pemberdayaan dapat dipahami dalam dua konteks. Pertama, kekuasaan dalam proses pembuatan keputusan dengan titik tekan pada pentingnya peran perempuan. Kedua, pemberdayaan dalam term yang berkaitan dengan fokus pada hubungan antara pemberdayaan perempuan dan akibatnya pada laki-laki di masyarakat yang beragam.(Zakiyah, 2010:44)

Terdapat dua ciri dari pemberdayaan perempuan. Pertama, sebagai refleksi kepentingan emansipatoris yang mendorong masyarakat berpartisipasi secara kolektif dalam pembangunan. Kedua, sebagai proses pelibatan diri individu atau masyarakat dalam proses pencerahan, penyadaran dan pengorganisasian kolektif sehingga mereka dapat berpartisi. (Zakiyah, 2010:44)

Adapun pemberdayaan terhadap perempuan adalah salah satu cara strategis untuk meningkatkan potensi perempuan dan meningkatkan peran perempuan baik di domain publik maupun domestik. Hal tersebut dapat dilakukan diantaranya dengan cara: (Ismah Salman, 2005:181)

1. Membongkar mitos kaum perempuan sebagai pelengkap dalam rumah tangga.

Pada zaman dahulu, muncul anggapan yang kuat dalam masyarakat bahwa kaum perempuan adalah konco wingking (teman di belakang) bagi suami serta anggapan "swarga nunut neraka katut" (ke surga ikut, ke neraka terbawa). Kata nunut dan katut dalam bahasa Jawa berkonotasi pasif dan tidak memiliki inisiatif, sehingga nasibnya sangat tergantung kepada suami.

2. Memberi beragam ketrampilan bagi kaum perempuan. Sehigga kaum perempuan juga dapat produktif dan tidak menggantungkan nasibnya terhadap kaum laki-laki. Berbagai ketrampilan bisa diajarkan, diantaranya: ketrampilan menjahit, menyulam serta berwirausaha dengan membuat kain batik dan berbagai jenis makanan.

3. Memberikan kesempatan seluas-luasnya terhadap kaum perempuan untuk bisa mengikuti atau menempuh pendidikan seluas mungkin. Hal ini diperlukan mengingat masih menguatnya paradigma masyarakat bahwa setinggi-tinggi pendidikan perempuan toh nantinya akan kembali ke dapur. Inilah yang mengakibatkan masih rendahnya (sebagian besar) pendidikan bagi perempuan. 
Berpijak dari pengalaman pemilu 2004 itu kemudian muncul gagasan untuk menerapkan zipper system dalam pemilu 2009. Sistem ini mengharuskan parpol untuk menyertakan sekurang-kurangnya satu caleg perempuan di antara tiga calon dalam posisi yang berurutan nomor urut. (Artikel: 2014) Gagasan itu tertuang dalam Undang-undang Nomor 10 Tahun 2008 tentang Pemilihan Umum. Pasal 55 ayat (2) Undang-undang Nomor 10 Tahun 2008 tentang Pemilihan Umum mengatakan, "Di dalam daftar bakal calon sebagaimana dimaksud pada ayat (1), setiap 3 (tiga) orang bakal calon terdapat sekurang-kurangnya 1 (satu) orang perempuan bakal calon." Pada ayat (1) mengatur bahwa namanama calon dalam daftar bakal calon disusun berdasarkan nomor urut.

Ketentuan zipper system diberlakukan untuk memaksa parpol agar lebih serius dalam menempatkan caleg perempuan pada nomor urut kecil sehingga memperbesar kemungkinan caleg bersangkutan memperoleh kursi di DPR. Meskipun demikian, parpol masih saja bersikap sinis dengan cara mengakali ketentuan tersebut melalui penempatan caleg perempuan di posisi nomor tiga dan kelipatan. Banyaknya jumlah caleg perempuan pada posisi nomor urut tiga dan enam memperlihatkan parpol sering kali menempatkan perempuan di opsi terakhir. (Artikel: 2014)

Penerapan ketentuan zipper system pun mengalami beberapa tantangan. Pertama, belum dijalankannya ketentuan itu secara maksimal akibat ketiadaan sanksi tegas terhadap parpol pelanggarnya. Parpol pelanggar hanya diminta untuk melakukan perbaikan daftar calon oleh KPU. Dalam kata lain, pelanggaran ini tidak memengaruhi nasib keikutsertaan parpol bersangkutan dalam pemilu. Kedua, pembatalan aturan nomor urut oleh Mahkamah Konstitusi pada Desember 2008. Keputusan Mahkamah Konstitusi itu telah membuat kuota 30 persen keterwakilan perempuan dan zipper system sebagai usaha tindakan afirmasi menjadi seakan tidak berarti lagi. Beruntung keputusan Mahkamah Kontitusi tersebut tidak berpengaruh besar terhadap tingkat keterpilihan caleg perempuan di pemilu 2009. Ketika itu tingkat keterpilihan caleg perempuan di DPR mencapai 18 persen. (Artikel: 2014)

Meskipun demikian, harus diakui secara umum parpol di Indonesia belum bersikap lapang dada dan maksimal dalam menerima tindakan afirmasi peningkatan keterwakilan perempuan di lembaga legislatif. Diperlukan perbaikanperbaikan mendasar dengan memberikan "tekanan politik" melalui perangkat regulasi kepada parpol sehingga dapat memaksa mereka untuk lebih menghargai tindakan afirmasi keterwakilan perempuan di lembaga legislatif.

Menurut konteks ini, keberadaan PKPU Nomor 7 Tahun 2013 menjadi terasa sangat berarti. Peraturan ini menegaskan mengenai sistem pencalonan anggota legislatif. Untuk persoalan mengenai pencalonan anggota legislatif perempuan, peraturan ini menegaskan beberapa hal, seperti kuota 30 persen perempuan di setiap daerah pemilihan dan urutan penempatan daftar bakal calon perempuan (dengan sistem dalam setiap tiga bakal calon harus ada satu bakal calon perempuan). Apabila ketentuan ini tidak dijalankan parpol, maka sanksi tegas menanti. Seluruh caleg dari parpol bersangkutan yang berada di daerah pemilihan yang tidak memenuhi syarat keterwakilan perempuan tersebut, akan dinyatakan gugur dan tidak bisa maju mengikuti pemilu.

Usaha untuk meningkatkan keterwakilan perempuan di parlemen hasil pemilu 2014 sejauh ini dapat dikatakan berhasil. Keberadaan UU No 8 Tahun 
2012 dan PKPU Nomor 7 Tahun 2013 berhasil memaksa parpol untuk memenuhi kuota 30 persen keterwakilan perempuan. Hal itu tercermin melalui jumlah caleg perempuan di daftar calon tetap untuk DPR periode 2014-2019. Dalam daftar itu, setiap parpol rata-rata memiliki caleg perempuan sebesar 34,25 persen

\section{Peran Keterwakilan Perempuan Dalam Parlemen Perspektif Hak Asasi Manusia}

Tujuan diselenggarakannya Pemilu adalah untuk memilih wakil rakyat dan wakil daerah serta untuk membentuk pemerintahan yang demokratis, kuat dan memperoleh dukungan rakyat dalam rangka mencapai tujuan negara sesuai dengan UUD NRI Tahun 1945. Kaitannya dengan perlindungan Hak Asasi Manusia, setiap warga Negara diberi jaminan untuk dapat mengikuti pemilihan umum yang diselenggarakan oleh Negaranya. Baik itu memilih ataupun dipilih dalam pemilu. Pasal 28D ayat (3) UUD NRI 1945 menyatakan bahwa, "Setiap warga negara berhak memperoleh kesempatan yang sama dalam pemerintahan.“ Artinya semua orang berhak ikut dalam pemerintahan termasuk dalam hal hak dipilih untuk menjadi wakil rakyat atau pun hak untuk memilih wakil rakyatnya (diluar konteks apakah nanti calon tersebut terpilih atau tidak) dan hal tersebut merupakan jaminan bagi hak asasi manusia di Indonesia.

Demokrasi memberikan kesempatan seluas-luasnya kepada seluruh warga negara yang memenuhi syarat untuk dapat memilih dan dipilih sebagai wakil rakyat tanpa adanya diskriminasi terhadap suku, ras, agama, dan gender. Dalam kaitannya dengan kesetaraan gender, ada himbauan CEDAW (Convention on The Elimination Of All Forms of Discrimination Againts Women) PBB tahun 1974 kepada Negara-negara yang menandatangani Konvensi yang telah dibuat (termasuk negara Indonesia yang diratiikasi dengan Undang-Undang Nomor 7 Tahun 1984 Tentang Pengesahan Konvensi mengenai Penghapusan Segala Bentuk Diskriminasi Terhadap Perempuan). Salah satu himbauan CEDAW PBB tersebut adalah untuk mengeliminasi segala bentuk diskriminasi terhadap perempuan dengan melakukan tindakan affirmatif. Tindakan affirmatif (affirmative actions) adalah tindakan khusus koreksi dan kompensasi dari negara atas ketidak adilan gender terhadap perempuan selama ini. (Imas Rosidawati, 2010).

Pasal 4 CEDAW PBB, menyatakan bahwa "tindakan affirmatif adalah langkah-langkah khusus sementara yang dilakukan untuk mencapai persamaan kesempatan dan perlakuan antara laki-laki dan perempuan". Pengertian awalnya adalah "hukum dan kebijakan yang mensyaratkan dikenakannya kepada kelompok tertentu pemberian konpensasi dalam keistimewaan dalam kasus-kasus tertentu guna mencapai representasi yang proporsional dalam beragam institusi dan pekerjaan. Di Indonesia, Salah satu tindakan affirmatif adalah dengan penetapan sisitem kuota sedikitnya $30 \%$ dalam institusi-institusi pembuatan kebijakan Negara.

Kebijakan afirmasi (affirmative action) atau kebijakan yang bersifat mendorong perempuan dalam bidang politik diterapkan, karena dunia politik masih diyakini kalangan feminis sebagai dunia yang arogan dan patriarkis. Akibatnya, komposisi perempuan di lembaga perwakilan tidak seimbang dengan jumlah penduduk perempuan. Keputusan yang dikeluarkan parlemen masih dianggap diskriminatif bagi perempuan. 
Kebijakan affirmasi 30\% adalah minimum atau sekurang-kurangnya atau paling sedikit, bukan "jatah" yang dimaknai tidak boleh melebihi dari jumlah yang ditentukan. Ketentuan keterwakilan perempuan minimal $30 \%$ di parlemen sama sekali tidak ditujukan untuk membatasi partisipasi perempuan dalam politik. Ketentuan ini justru merupakan tindakan khusus sementara (temporary special measure) agar hak-hak perempuan yang selama ini didiskriminasi oleh nilai-nilai budaya yang dikonstruksi dalam masyarakat dapat ditegakkan. (Titik Sumbung: 2003)

Pentingnya keterwakilan perempuan secara proporsional tidak sematamata untuk merepresentasikan proporsionalitas jumlah penduduk perempuan Indonesia. Hal ini justru sekaligus sebagai bentuk pengakuan dan kesempatan yang sama atas harkat dan martabat perempuan sebagai warga negara yang diperlakukan sama dengan warga negara laki-laki oleh Bangsa Indonesia.

Menurut Hanna Pitkin sebagaimana dikutip Nuri Soeseno ada empat pandangan yang berbeda mengenai keterwakilan, yaitu: (1) keterwakilan formal; (2) keterwakilan simbolis; (3) keterwakilan deskriptif; dan (4) keterwakilan substantif. Keterwakilan formal merupakan keterwakilan yang terbentuk sebagai hasil pengaturan institusional yang dilakukan sebelum keterwakilan ada. Keterwakilan deskriptif merupakan sebuah bentuk keterwakilan yang berdasarkan pada persamaan atau kemiripan antara wakil dan yang diwakili (konstituen atau pemilih). Adapun keterwakilan substantif merupakan konsep keterwakilan yang menunjukkan bahwa kegiatan yang dilakukan oleh seorang wakil adalah untuk kepentingan yang diwakilinya. (Nuri Soeseno, 2014).

Terkait dengan keterwakilan perempuan dalam politik dilihat dari $30 \%$ keberadaan perempuan dalam parpol dan dalam daftar caleg Pemilu 2014, Nuri Soeseno menyatakan bahwa sebagai konsekuensi kuota, cara-cara parpol merekrut caleg pada Pemilu 2014 dan posisi perempuan dalam struktur kepengurusan partai, maka dapat dikatakan bahwa keterwakilan perempuan dalam politik masih bersifat deskriptif. Apabila berbagai ketentuan mengenai kuota 30\% untuk perempuan membawa hasil dan angka $30 \%$ tersebut dapat tercapai maka ada harapan bahwa keterwakilan deskriptif tersebut dapat memunculkan keterwakilan substantif. Akan tetapi hasil Pemilu 2014 menunjukkan bahwa keterwakilan perempuan tidak mencapai $30 \%$, bahkan menurun jika dibandingkan dengan pemilu sebelumnya (2009). Oleh karena itu, kita tidak dapat berharap banyak akan munculnya keterwakilan substantif perempuan dalam politik.

Permasalahan dari representasi perempuan dalam parlemen, bukan sekedar tantangan untuk meningkatkan kuantitas tetapi juga peningkatan kualitas. Tujuan yang lebih besar yaitu bagaimana partisipasi politik perempuan bermakna/transformatif dan dapat merubah agenda politik menjadi lebih membumi, serta berpihak pada kesejahteraan masyarakat. Keterlibatan perempuan diharapkan dapat membawa perspektif baru dalam proses politik dan penentuan prioritas mengenai isu yang akan dibahas. Dinamika perjuangan perempuan di parlemen harus mampu merespon isu kritis yang berkembang di tengah masyarakat. Hal ini adalah konsekuensi dari komitmen perempuan dalam menjalankan politik. Makna strategi representasi perempuan di parlemen, yaitu untuk melakukan pembaharuan substansi, struktur dan kultur legislasi.

Hak asasi manusia tidak membedakan antara laki-laki dan perempuan, dengan asas persamaan di dalam hukum dan pemerintahan. Penting untuk disadari 
bahwa berbagai pengetahuan, konsep dan kebijakan yang dipahami oleh masyarakat hingga saat ini, termasuk konsep hak-hak asasi manusiai, lebih merefleksikan perspektif dan kepentingan laki-laki. Perspektif ini kemudian digeneralisasikan ke seluruh umat manusia, perempuan dan laki-laki. Perspektif kaum perempuan, yang jumlahnya $50 \%$ dari populasi manusia kurang memperoleh perhatian. Padahal perempuan memiliki pengalaman sosial dan pengalaman ketubuhan (dengan potensi reproduksinya yang khusus) berbeda, yang berdampak pada sudut pandang, dan kebutuhan yang perlu dipahami secara khusus. Terlebih lagi, konstruksi sosial dan pemaknaan terhadap potensi reproduksi perempuan sering bersifat mendiskriminasi perempuan, yang berdampak pada kesulitan dan situasi-situasi khusus perempuan, yang memerlukan penanganan khusus.

Kenyataan dalam masyarakat Indonesia, kesetaraan dalam memperoleh manfaat yang sama dan adil dari hasil-hasil pembangunan antara laki laki dan perempuan (termasuk di dalamnya anak perempuan) belum tercapai, terutama disebabkan masih sangat kuatnya budaya patriarkhi dan perspektif laki-laki dalam mempengaruhi pola pikir, pola perilaku, dan pengambilan keputusan termasuk pengambilan kebijakan.

Kepedulian atas kesejahteraan perempuan bermakna pada kesungguhan upaya untuk mendukung pemenuhan hal-hal yang dibutuhkan agar perempuan bisa diberdayakan untuk pembangunan nasional, kesempatan yang sama dalam memperoleh pendidikan yang berkualitas, serta kesempatan untuk belajar menjadi bagian dari proses di dalam masyarakatnya. Kepedulian atas pemberdayaan perempuan bermakna pada kesungguhan upaya untuk memastikan bahwa setiap perempuan dapat juga untuk berkembang sesuai dengan bakat yang dimilikinya

\section{Penutup}

Persoalan mengenai keterwakilan perempuan di parlemen, tidak dapat dimungkiri masih menghadapi sejumlah tantangan, baik internal maupun eksternal. Padahal sebagai warga negara seluruh hak kaum perempuan dijamin konstitusi, termasuk hak untuk berpartisipasi di bidang politik. Bahkan, jaminan terhadap hak politik kaum perempuan tidak hanya di tingkat nasional, tapi juga di tingkat global seperti Konvensi Hak-hak Politik Wanita dalam Piagam Perserikatan Bangsa-Bangsa dan Convention on the Elimination of All Forms Discrimination Against Women.

Kendala-kendala internal antara lain berupa masih lemahnya kualitas sumber daya manusia sebagian besar kaum perempuan, terbatasnya jumlah kaum perempuan yang memiliki kualitas dan kualifikasi mumpuni di bidang politik, dan rasa kurang percaya diri untuk bersaing dengan kaum laki-laki. Sementara itu, kendala-kendala eksternal antara lain adalah kultur masyarakat Indonesia yang cenderung patriarki, ketiadaan kemauan politik elite-elite partai untuk membuka ruang luas bagi keterlibatan kaum perempuan, dan sikap sebagian kaum laki-laki yang meremehkan kemampuan kaum perempuan di bidang politik. 


\section{DAFTAR PUSTAKA}

Artikel, Parlemen Perempuan\Keterwakilan Politik Perempuan - Panduan Gaya Hidup Pria Intelektual_Esquire.co.id.htm. 2014

http://www.bps.go.id/booklet/Boklet\%20November_2011.pdf.

Imas Rosidawati, Makalah, Keterwakilan Perempuan di Dewan Perwakilan Rakat Kesiapan Partai Politik\& Perempuan Indonesia di Arena Politik Praktis.

Ismah Salman, Keluarga Sakinah dalam Aisyiyah, Jakarta: PSAP Muhammadiyah, 2005, cet. Ke-1

Kompas, 13 Mei 2014 “Jumlah Perempuan di DPR 2014-2019 Berkurang,”

Nuri Soeseno, "Perempuan Politisi dalam Partai Politik Pemilu 2014: Keterwakilan Deskriptif vs Substantif', dalam Jurnal Perempuan No. 81: Perempuan Politisi, Mei 2014. Jakarta: Yayasan Jurnal Perempuan

Suharizal dan Delfina Gusman, Suatu Kajian Atas Keterwakilan Perempuan Di DPRD Propinsi Sumatera Barat, Makalah, 2010.

Titi Sumbung,"Caleg Partai Peserta Pemilu Minimum 30\% Perempuan, Siapa Takut?!", Rilis Jaringan Perempuan dan Politik, 2003

Zakiyah, Pemberdayaan Perempuan oleh Lajnah Wanita, Jurnal Pengkajian Masalah Sosial Keagamaan, XVII, 01 (Januari-Juni 2010), h.44 